ACTA MYCOLOGICA

Vol. 41 (1): 79-94

2006
Dedicated to

Prof Dr. Alina Skirgietzo,

Warszawa, with motivation

of her 95th birthday

\title{
Global warming and mycoflora in the Baltic Region
}

\author{
HANNS KREISEL
}

Zur Schwedenschanze 4, D 17498 Potthagen, hanns.kreisel@gmx.de

Kre is el H.: Global warming and mycoflora in the Baltic Region. Acta Mycol. 41 (1): 79 94, 2006.

The author discusses possible effects of global warming on distribution and ecology of larger fungi, and presents examples of suggested indicator species which apparently are spreading from south to north. Only Basidiomycetes are corncerned, while actually no case of non lichenized Ascomycetes is known. A continued monitoring of the mentioned species is recommended.

Key words: mycoflora, Basidiomycetes, global warming, Baltic Region

\section{INTRODUCTION}

Global warming (climatic change) with its consequences for weather and local climate, rising sea level, retreat of glaciers and of polar ice calottes, and subsequent nature catastrophes, actually is much disputed in newspapers, journals, and book publications. Highly reputed specialists of climatology, oceanography, or physics, have investigated the phenomena (e. g. Rahmstorf, Schellnhuber 2006).

Since the end of last Ice Age, some 15000 years ago, climate in central and northern Europe is warming, and enormous ice calottes have retired from this region, making possible a re-settelement of large areas by vegetation and fauna. This process was not continuous, but interrupted by phases of standstill alternating with phases of further warming. Nevertheless, the actual phase of relatively fast warming is regarded as man-made to a large extent, and therefore requires special attention by scientists.

Also in mycology, we are contemporary witnesses of changes in distribution and ecology of fungi, and we should use the chance to observe and describe the corresponding evolutions.

During the last decenniums, attention of mycologists was concentrated on processes of threat and decline of mycoflora by presumably man-made factors, with subsequent publication of a rich literature of Red Data Lists and evaluations of long registers of species regarded as endangered in different degrees. 
This is not the place to discuss whether or not it is possible to conserve the mycoflora of a given territory in its actual composition and status, but we should be aware that we are living on a planet which is in permanent evolution since thousands millions of years, and will continue to evolve.

Up to date, only a few mycologists, and only in a few special cases, have discussed the consequences of global warming. But there is an interesting paper of Dutch lichenologists (Herk et al. 2002) who have found, basing on a long-term monitoring, that many tropical and subtropical species of epiphytic and terrestrial lichen species are invading the Netherlands, while already $50 \%$ of the arctic-alpine and boreomontane species shows a decline.

If we are looking for comparable processes in non-lichenized larger fungi, we only can form a general picture by comparison of many small detailed informations. Judging from experiences and publications from central and northern Europe, in particular from countries around the Baltic Sea, the following impressions raise:

1. A number of species is moving from southern countries (mainly the submediterranean region) to north. But this is not an advance on broad front, but only in more or less isolated localities, volatile, and interrupted by temporary retreats.

2. Main fructification time of macromycetes is shifting from late summer and early fall to late fall, even beginning winter. This remembers the situation in regions with mediterranean clima. Organizers of forays, mushroom exhibitions and similar events already had to note this phenomenon by success or failure of their efforts.

3. Consequences of climate on annual mushroom yield have been supposed by Richter $(2005,2006)$. In an area north of Berlin he demonstrated a positive trend in the period 1977 - 2003 for Cantharellus cibarius, Boletus edulis, Sparassis crispa, and Gyroporus cyanescens, while the yield of Xerocomus badius and Amanita rubescens was showing a decrease. On increasing frequency of the poisonous Agaricus xanthodermus see above.

In the following lines, only the first aspect shall be considered and substantiated by some facts and data.

\section{WOOD INHABITING MACROMYCETES}

Auricularia mesenterica (Dicks. : Fr.) Pers. was known in central Germany already in the 19th century, but only since 1970 ist is known in northern Germany (Baltic coast), and 1983 in lower Elbe valley (Wöld e cke 1998; O t to et al. 2005 map). The actual extension of its area has reached southern Norway and central Sweden (Ryman, Holmåsen 1984, map).

Coriolopsis trogii (Berk.) Dom. [Trametes trogii Berk.]

This species seems to be indigenous in the Rhine valley from SW. Germany to Netherlands, in the Inn valley of SE. Bavaria, in Moravia and Slovakia (Kotlaba 1984, map; Krieglsteiner 1991, map; Arnolds et al. 1995, map). Outposts in central and northern Germany were noted 1945 near Alsfeld, Hessen and 1961 near Detmold (Kreisel 1962), 1977 in Berlin (Kaspar 1979), 1996 near Merseburg (Richter, Schurig 1997), 1998 near Borna, Saxonia (Hardtke, Otto 1998), and 2004 near Braunschweig (An de rss on 2004). In Poland the species has reached central Poland (Niemelä et al. 1992), and in Scandinavia isolated localities in southern Norway, central Sweden and south-eastern Finland (Olofsson 
1996, map; Vesterholt in Hansen, Knudsen 1997; Larsson 1997, map). Up to date, there seems to be no record from Denmark.

Diplomitoporus flavescens (Bres.) Dom. [Trametes flavescens BREs.]. This species, bound to Pinus spp., was known around 1970 to occur north to southern Germany, eastern Saxonia (D ung e r 1987), southern and eastern Poland (Woj ew od a 2003); it was discovered 1974 in southern Brandenburg (eastern Germany), 1983 in Berlin and after 1994 north of Berlin (Benkert 2004, maps), it was found before 1983 in the Słowinski National Park, northern Poland (Bujakiewicz, Lisiewska 1983), and 1986 in the Netherlands (Arnolds \& al. 1995). In Sweden, only 3 localities have been noted before 1996 (Olofs s on 1996, map).

Ganoderma adspersum (Schulzer) Donk [G. australe (FR.) PAT. agg.] is considered as an expanding species by several authors (ARNOLDS \& al. 1995 for Netherlands, Kreisel 1998, with map, for eastern Germany, Wojew oda 2003 for Poland). Although known from Prague as early as 1851 (Kotlab a 1984, map), it was found only 1959 near Detmold, 1960 near Potsdam, 1961 near Dresden, 1964 near Stralsund, 1981 on Fyn and Sjaelland (Denmark), 1986 on the Frisian island Langeoog, 1996 at the southern coast of Sweden, and 1997 in Oslo, Norway (J a h n 1963; Pe te r s e n 1983; Kreisel 1987; Olofsson 1996, map; Kreisel 1998, map; Wöldecke 1998).

Ganoderma pfeifferi Bres. The species occurs mainly on liv-ing truncs of Fagus sylvativa. It was known already 1860 near Greifswald and 1864 on Lolland, Denmark (Petersen 1983; Kreisel 1998, map), but was recorded only 1971 ff in Skåne, southern-most Sweden (Bohlin 1971), and later in Blekinge and Väster-götland, Sweden (Ol of s s on 1996, map; La r s s on 1997). In Poland its distribution probably is synanthropic (Wojew oda 2003).

Ganoderma resinaceum Boud. This another southern Ganoderma species "going north". It was recorded 1910 in southern Moravia (Kotlaba 1984), 1930 in eastern Saxonia, 1932 near Darmstadt, Hessen, 1943 ff in the Netherlands (after 1970 increasing there), 1950 in Lolland, Denmark, 1963 Westfalen, 1981 ff in Niedersachsen, Germany, 1987 in Halland, Sweden, but only 1995 ff in Rostock and other places along the Baltic coast in North Germany (Jahn 1963; Petersen 1983; Arnolds 1995; Olofss on 1996, map; Kre isel 1998, map).

Hirneola auricula-judae (Bull. : Fr.) Wettst. [Auricularia auricula-judae (Bull. : Fr.) Berk.] is actually quite common in Germany and Poland and was recorded as early as 1721 in central Germany and 1753 in eastern Brandenburg (Täglich 1998; Benkert 2004), but there is a distinct increase of its frequency after 1970 in northern Germany (B e n kert 2004 with maps; Kreisel n. p.). A significant spreading was noted after 1945 in Denmark and southern Sweden (Knudsen \& Pedersen 1980, maps) and after 1980 in the Netherlands (Nauta, Velling a 1995).

Inonotus nidus-pici Pilát was observed since 1887 in Czechoslovakia (Kotlaba 1984), but appeared 1967 in Potsdam, 1977 near Eberswalde, 1978 near Parchim, 1984 ff in and around Demmin, and 1985 near Rostock, all in northern Germany (Benkert 1971; Kreisel 1994, map). Strangely enough, there is no record of this submediterranean species from the neighbour regions Poland and western Germany, and there are no more records from Germany after 2000. Up to date the species was not recorded from Denmark and Fennoscandia. 
Mutinus caninus (Huds. : Pers.) Fr. The species is common in forests of central Europe and Denmark for a long time, but its immigration in Scandinavia is described by Andersson (1941). Actually it is rare in Norway and Sweden, and known from only one locality in south-western Finland (Eckblad in Hansen, Knudsen 1997).

Pluteus aurantiorugosus (Trog) Sacc. [P. coccineus (Massee) J. E. Lange] is rare, but widely distributed in central Europe, in the Netherlands and in southern Poland (Kreisel 1987; Krieglsteiner 1991, map; Arnolds 1995; Wojewoda 2003), being more frequent only in south-western Germany and the Rhine valley. It was recorded in Jylland, Denmark, 1917 ff (Lange 1936), but only since 1984 in northern Germany (Kreisel 1987; Otto et al. 2005, map). In recent times it appeared in Sweden from Skåne to Västergötland and Öland (Larsson 1997), and 2002 in Norway near Oslo (Gulden 2002).

Polyporus alveolaris (DC. : Fr.) Bondartsev \& Singer [P. mori Pollini: Fr., Favolus europaeus Fr.] has been found already in the 19th century in Czechoslovakia (PILÁT 1936; Kotlaba 1984). In Germany it was recorded 1929 in the Black Forest (Schwarzwald) and is now widely distributed in south-western Germany and eastern Bavaria, extending north to the Main valley and the Eifel Mts. (Krieglsteiner 1991, map; Lohmeyer 2003). In Poland it was found 1999 near Tarnów and recently along Odra river near Kostrzyn and Szczecin (Wojew od a 2003). Up to date, there are no records from North Germany, Denmark, and Scandinavia.

Sarcodontia crocea (Schwein. : Fr.) Kotl. [S. crocea (Pers.) Donk] has penetrated in two periods to the Baltic region. In the 19th century, the northern limit of its distribution was marked by Göttingen, Dessau, Görlitz, Legnica, Wroclaw, Kraków, and Bieszczady Mts. (Kre is el 1991; Wojew od a 1973, 2003), but around 1900 several records were noted around Berlin, 1902 on Öland (Sweden), moreover near Gamborg (Fyn, Denmark), 1928 near Lublin in Poland and 1933 near Elbing (Elbląg). All of these outposts were extinct for several decenniums, but in 1970 another advance started in NE Germany: 1970 near Guben, 1970 and 1979 Rostock, 1975 Potsdam, 1980 Neubrandenburg, 1983 Berlin-Mahlsdorf, 1990 Greifswald and near Wismar. Simultaneously, the species appeared in the Netherlands (prov. Zeeland) in 1975 and 1984 (Arnolds et al. 1995). In southernmost Finland now the $61^{\circ}$ latitude is reached (Schumacher 2005).

Schizophyllum commune Fr. : Fr. Although the Common Split-gill was observed in central Europe and in Denmark already in the 18th century, there was a notable increase in frequency and distribution since 1932 in Denmark and since 1948 on Bornholm island (Bjørnekaer, Buchwald 1933; Knudsen, Pedersen 1983, maps), after 1950 in northeastern Germany (Dörfelt et al. 1988, map). The actual distribution reaches southern Norway, southern and central Sweden and southern Finland (Ryman, Holmåsen 1984, map; Käärik in Hansen, Knudsen 1997). In contrary, a decrease was noted since 1980 in the Netherlands (Na u ta, Velling a 1995).

Less distinctive appear the cases of some wood-inhabiting saprobic agarics and boletes, regarded as "southern species", as Haasiella venustissima (Fr.) Kotl. \& Pouzar, Pulveroboletus hemichrysus (Berk. \& M. A. Curtis) Singer, Rhodotus palmatus (Bull. : Fr.) Maire. These deserve further attention and monitoring, for they have been noted occasionally and inconsistently in northern Germany and Scandinavia. 
H. venus-tissima and Rh. palmatus have been observed in Sweden already in the 19th century. Such early outpost records may be interpreted as relicts of a former warming period - but in that time, number of observers was too low, and mapping was not applied, therefore no clear evidence is available. Another wood-inhabiting species to be monitored carefully is Plicatura crispa (Pers. : Fr.) Rea [P. faginea P. Karst.] for actually it is advancing (or re-settling lost areas ?) in central and northern Germany, but it is not clear whether or not this can be interpreted as consequence of Global Warming.

\section{SOIL AND LITTER INHABITING SAPROBES}

Agaricus bohusii Bon, a species occuring mainly in alluvial forests and on synanthropic habitats, was observed since 1922 in Bohemia, but only since 1969 in Hungary, 1978 in central Germany near Halle , 1981 near Magdeburg, before 1984 in Poland near Bielsko-Biała, 1986 in Hannover, 1990 near Leipzig, 1993 near Zittau, 2000 near Wismar (Herrmann 1987; Wöldecke 1998; Wojewoda 2003; Specht 2005; Otto et al. 2005, map); in Denmark it was recorded since 1993 in Copenhagen, and since 1998 near Aarhus, Jylland (Petersen 2006). It was rarely found in the Netherlands (Arnolds et al. 1995), but still not recorded from Scandinavia.

Agaricus xanthodermus Genev., the poisonous Yellow-staining Mushroom, is common in nearly the whole Germany (Krieglsteiner 1991, map; Otto \& al. 1994, map), Netherlands, Denmark, Poland (Skirgiełło 1986, map), Hungary etc., but rare in southern Scandinavia (Hansen, Knudsen 1992; Ryman, Holmås e n 1984, map). Recently, several observers in central and northern Germany have noted a discinct increase in frequency of this species.

Clathrus archeri (Berk.) Dring [Anthurus archeri (Berk.) E. Fisch.] is a frequently documented and mapped case. The species, apparently introduced from Australia, appeared 1914 in eastern France (Vosges Mts.), 1938 in Germany near Karlsruhe (Rhine valley), 1942 near Basel in Switzerland, 1948 in Austria, 1965 in western Bohemia, 1985 in southern Poland and 1989 in Slovakia. In Germany, the species extended continuously to north: 1953 it was found in the Main valley, an important biogeographic line (Stricker 1954, maps), 1960 near Querfurt in central Germany (Herrmann 1962, 1971), 1963 near Meißen (Saxonia), 1977 in the Harz Mts. and in Rostock near Baltic Sea, 1981 ff Lower Saxonia, 1984 ff near Greifswald. There is one record from Denmark (Fyn), but only an erroneous record 1942 in Norway. In the Netherlands the species appears since 1973 and is spreading (ARNOLDS \& al. 1995). The early appearence of the species since 1945 in Cornwall, southwestern England, may be due to another introduction. For a rather actual map of distribution in Europe see Kreisel (2004), for Poland Stengl-Rejthar, Wojewoda (1985), eastern Germany Dörfelt et al. (1988), Czechoslovakia Kluzák (1990), western Germany Krieglsteiner (1991). C. archeri meanwhile is naturalized in forests in wide parts of central Europe, whereas its habitats in northern Germany are mainly cemeteries, parks, recreational forest areas near towns, and other synanthropic places.

Conocybe intrusa (Peck) Singer [C. hebelomatoides Middelhoek \& Reijnders]. The strange agaric, possibly introduced from North America, was observed in Eu- 
rope first 1950 in Hengelo, Netherlands (Arnolds et al. 1995), 1968 and 1971 in Berlin (Benkert 2005) and then in several places around Berlin and in central Germany, including 1977 Zittau (Herrmann 1976; Eder 1983; Dörfelt et al. 1988, map), 1979 ff an a few places in Lower Saxonia (Wöld e cke 1998), 1987 near Greifswald, and 1997 Wyszków in central Poland (Wojewoda 2003), but already 1973 in Lithuania (Urbon a s et al. 1986). Many of the records are from glasshouses, but others from gardens, vegetable waste, manure heaps, and other open places.

Lycoperdon marginatum Vittad., a species of open grassland on gravelly or sandy soil, of mainly southern distribution, was rare everywhere in central Europe. In northern Germany it was found 1902 and 1905 around Berlin and rediscovered 1970 near Potsdam, 1984 near Görlitz, and 2003 near Zessin on the Rügen island (B e n k ert 1973; Hardtke, Otto 1998; Kreisel 2005).

Mutinus elegans (Mont.) E. Fisch. [M. curtisii (Berk.) E. Fisch., M. inopinatus U1brich] is another species of North American origin. In Europe it was first noted 1929 at Lago Maggiore in northern Italy (Stomps 1931), 1936 in lower Rhine valley in north-western Germany (Ulbrich 1937), 1948 near Karlsruhe, 1977 ff in Saxonia, $1982 \mathrm{ff}$ in Berlin, $1984 \mathrm{ff}$ near Pasewalk in north-eastern Germany, the last being actually the northernmost locality in Europe (Kreisel 1987; Rauschert, Hellmund 1989; Hardtke, Ot to 1998; Kre is el 2004, map). M. elegans was observed in Germany mainly in gardens, frequently associated with tall grasses (Miscanthus spp., Arundo donax, Be n kert 2005). In the Netherlands it was found only 1989 near Ede (Arnolds et al. 1995; Nauta, Vellinga 1995). There are no records from Denmark, Scandinavia, and Poland.

Mutinus ravenelii (Berk. \& M. A. Curtis) E. Fisch. was equally introduced from North America and was noted at first 1942 in Berlin. In contrary to M. elegans, it expanded mainly to north and was found after 1950 in the Netherlands, 1960 near Hamburg, 1961 in Riga and southern Finland (here 1981 already in Oulu), 1968 - 1984 again in Berlin (Benkert, Jentsch 1985), and is knowm from rare collections in Denmark, Sweden, and Norway. In Germany, a certain concentration of localities has established around Hamburg, and in the Spreewald estuary SE of Berlin. In eastern Europe, M. ravenelii is known from Bohemia (Ku than, Veselský 1967; Sedláček, Skála 1985; Bícha 1986), 1969 ff from southern and central Poland (Guminska 1985; Sokół, Szczepka 1987, map), about 1980 from Latvia and Estonia (Vimba, Yarva 1981; Järva, Vimba 1981). A map of distribution in Europe was published by Kreisel (2004).

In summary, most saprobic soil-inhabiting species recorded in part B are introduced from other continents or of unknown origin.

\section{ECTOMYCORRHIZAL FUNGI}

Amanita phalloides (Fr.) Link is a frequent species in most of central Europe, distributed since old times from submedi-terranean region till Baltic Sea, e. g. in Germany, Poland, Denmark, and the Baltic states. In Fennoscandia, it is restricted to the Fagus and Quercus belt, north till Hordaland in Norway, southern Sweden, Åland islands, and south-western Finland. The first record near Oslo was registered only 2000 by Brandrud (2001), what suggests a slight extension to north in Norway. In contrary, in nort-western Germany it is scarce (Krieglste in e r 1991, map), 
and in the Netherlands there is a significant decline (Nauta, Velling a 1995, but see Arnolds et al. 1995).

Amanita solitaria (Bull. : Fr.) Mérat ist frequent in the warmer parts of southern Germany, but rare in central Germany north to the Harz region, and very rare in the Netherlands. In northern Germany it was discovered 1989 near Braunschweig (Wöldecke 1998), 1997 near Templin (Doll 2001), and 2002 near Schwerin (Kreisel 2004). Distribution in western Germany was mapped by Krieglste in e r (1991). The species is not known from Poland and Fennoscandia.

Amanita verna (Bull. : Fr.) Roques should not be confused with albinotic forms of $A$. phalloides. The true $A$. verna is a more thermophilous mushroom which occurs in Germany only north to Saarland and the Main valley (Krieglsteiner 1991, map). It does not occur in the Netherlands (Arnolds et al. 1995) and probably not in Poland (Wojew oda 2003), but it was recently introduced to Saxonia and caused there (near Bautzen) in 2005 a severe case of poisoning, recorded in television and newspapers; the fungi were determined by the mycologist G. Zschieschang (W. Tietze in litt.). The case shows how advance of southern species has implications even to toxicology and popular mycology.

Amanita vittadinii (Moretti) Vittad. is distributed in Europe mainly in the Mediterranean region. Since 1942 it was observed in Netherlands near Delft, where it is stable for more than 50 years within a very limited area (Arnolds et al. 1995). Since 1986 is was observed in central Germany near Merseburg (Dörfelt 1989), and 1992 it was found in Hannover (Wöldecke 1998). Up to date, there is no record from northern Germany, Poland, and Fennoscandia.

Chalciporus rubinus (W. G. Sm.) Singer [Boletus rubinus W. G. Sm.]. Although originally described in 1868 from England, the main distribution of this rare species seems to be in France, Italy, Austria, Hungary, southern Moravia, and Bohemia (Pilát, Dermek 1974). Since 1933 it was observed repeatedly in Saxonia in and near Dresden, 2000 ff. in Leipzig (Kle ine et al. 2005), 2005 in Rühstädt at lower Elbe (D. Benkert in litt.); in the Netherlands it was found 1993 in Utrecht (Ar nolds et al. 1995). All records from Germany and the Netherlands are from old parks on alluvial riverside habitats.

Cortinarius orellanus Fr. [Dermocybe orellana (Fr.) Ricken]. This is another poisonous mushroom which actually seems to be in expansion. In Germany it is rather frequent in the south-west, more rare in the other parts, and rare in the north (Krieglsteiner 1991, map; Otto et al. 1994, map). In Poland it is scattered mainly in southern and eastern Poland, but was recorded recently near Szczecin (Wojew od a 2003). It is rare in Denmark and southern Sweden (north to Bohuslän and Gotland, Larss on 1997), but a recent advance in southern Norway was documented by Brandrud (2001, map).

Pulveroboletus gentilis (Quél.) Singer [P. cramesinus (Secr. ex Gilbert) M. M. Moser] is regarded as thermophilic and calciphilic in Germany, where it occurs scattered in the southern and central parts (Krieglsteiner 1991, map; Ot to et al. 1994, map), whereas it is rare in Poland (Wojew od a 2003) and in the Netherlands (Nauta, Vellinga 1995 "regarded as threatened", map). In northern Germany recently a few localities have been recorded near Lübeck (Unger 1998) and 2003 near Schwerin (B. Westphal in litt.). Isolated localities are known from Denmark and Norway (Knudsen in Hansen, Knudsen 1992), whereas in Sweden it is 
known from several places from Skåne north to Götaland and Stockholm (La r s s o n 1997, map). It is not clear, whether or not a recent expansion is occurring in northern Germany and Scandinavia.

Scleroderma cepa Pers. The thermophilic species is rare in whole Germany, Poland, and Netherlands, but is known also from Denmark and southern Sweden (Hansen, Knudsen 1997). Some more recent records from Lower Saxonia 1969 ff (Wöldecke 1998), near Lübeck 1982 (Unger 1994) and 2005 in south-western Saxonia (Ch. Morgner in litt.) suggest a slight increase in frequency in central and northern Germany, but in northern Poland it was recorded by Te odorowicz already 1939 near Gdańsk. Few mycologists in central Europe are really familiar with this species, but the useful and illustrated keys published recently in Italy and Spain will facilitate a more thorough study of the distribu-tion of $S$. cepa in next future.

\section{FUNGI OF XEROTHERMIC GRASSLAND}

Endoptychum agaricoides Czern. The secotioid mushroom, widespread in xeric climates of Mediterranean region, SE. Europe and central Asia, goes north to aoutheastern Moravia and southern Slovakia. Only two outposts in the area considered here have been stated: 1941 near Sollentuna, Uppland in central Sweden (Arwids son 1945; Larsson 1997), and 1985 near Potsdam in eastern Germany (Kre is el 1995). Both localities were ephemerous and apparently independent of each other.

Floccularia straminea (P. Kumm.) Pouzar [Armillaria luteo-virens (Alb. \& Schwein. : Fr.) Gill. ss. auct. mult.]. This agaric occurs scattered in Bavaria and in central Germany till north of Harz Mts. (Herrmann 1971; Krieglsteiner 1991, map; Gröger in Kreisel 1987), in Poland only in Tatry National Park (Wojewoda 2003), but is lacking in the Netherlands, whole northern Germany, and most of Poland, but a very few temporary outposts have been observed in Scandinavia: one in Buskerud, southern Norway (Gulden in Hansen, Knudsen 1992) and two in Sweden: about 1940 near Stockholm, and 1988 at Visby on Gotland (Bohus Jensen et al. 1990; Larsson 1997).

Gastrosporium simplex Mattir. The "Steppe Truffle" was observed since 1956 in many localities in central Germany, from Thuringian bassin till north of Harz (Rauschert 1962, map) and in the Rhine-Main disctrict (Krieglsteiner 1991, map). Very few records exist from north-eastern Germany, where it was found at Seelow near Oder and at Altentreptow (Dörfelt, Rauschert in Kreisel 1987). In Poland, there are records from southern Poland and again in the Odra region at Bielinek nad Odrą (Šm a rda 1957) and Pyrzyce (Woj ew od a 2003). Since 1980 the species is known from a few localities in Sweden: Skåne and Västergötland (Ke rs 1980; Larss on 1997).

Geastrum pseudolimbatum Hollós. Our knowledge about this species is incomplete, for it was not distinguished from G. coronatum PERs. by several authors. It is very rare in xero-thermic regions of eastern Germany (Dörfelt et al. 1979, map), but lacking in western Germany. There are two records in Netherlands (1929 and 1980, Arnolds et al. 1995) and two in Sweden (Skåne and Västergötland, Su n hede 1989; Lars son 1997), but none from Poland.

Montagnea radiosa (Pallas) Šebek [M. arenaria (DC.) Zeller]. A frequent inhabitant of continental steppes and semideserts, it was discovered 1964 near Mücheln in 
central Germany, where it still was confirmed in 1995 and 1996, and in a few other localities near Erfurt and Halle (Rauschert 1964; Dörfelt 1974, map; Kre isel 1987; Dörfelt, Richter 1996). Further outposts exist in Poland near Bielinek nad Odrą (Skirgiełło 1977) and more recently near Pyrzyce in northwestern Poland and near Przemysl (Wojewoda 2003). Up to date, the species is not known from western Germany, Netherlands, Denmark, and Scandinavia.

Mycenastrum corium (Guersent) Desv. The rather well documented history of retreat and advance of this conspicuous nitrophilous puffball was largely described and discussed by Kreisel (1982, maps), Dörfelt, Bresinsky (2003, map), and Benkert 2004 (maps). It extended from south-eastern Europe or other continental regions to Germany where it was found 1860 and 1889 near Berlin, but then disappeared for several decenniums. From 1960 to 1992 many localities have been noted in most of eastern Germany, but only one isolated locality could be recorded in western Germany: 1982 near Heidelberg (Winterhoff 2000), and a doubtful record from the Fichtelgebirge Mts. After 1992 M. corium again became rare in eastern Germany, but in 2005 the species was still existent in a few localities near Anklam, north-eastern Germany. In Poland, the species is known since 1890 and is registered from scattered places in southern and central Poland (Wojew od a 2003).

In Scandinavia, M. corium was known as early as 1849 near Malmö, and a series of localities became recorded in Sweden from Skåne through Uppland till Umeå and, frequently, on Öland (Lundqvist 1961; Larss on 1997, map). There are a few records from south-western Finland and Aland islands (Ulvinen in Ha ns e n, Knudsen 1997). M. corium appeared 1961 on the Danish island Sprog $\varnothing$ (HANSEN 1962) and 1976 on Bornholm (Borgen 1977), and 1992 in southern Norway (Eckbla d 1992). In the Netherlands, M. corium was observed 1976, 1977, and 1981 (Ar nolds et al. 1995), and further records were from Belgium and France.

Dörfelt, Bresinsky (2003) regard $M$. corium is an excellent indicator species for climatic changes (continentalization). A monitoring and continued mapping in far-reaching scale will be useful even in future.

Pleurotus eryngii (DC.: Fr.) Quél. is very rare north of its Mediterranean and submediterranean main area. There are a few records from the Netherlands (Arnolds et al. 1995), and two in Rheinland-Pfalz, western Germany (Krieglste in er 1991, map). An ephemerous record in 1916 near Elbląg (Elbing) in northern Poland is mentioned by Wojewoda (2003). There are no records from eastern Germany, Denmark, and Scandinavia.

Polyporus rhizophilus Pat. was known since 1930 in southern Moravia, 1935 in Slovakia, 1951 near Prague and since 1962 in the Bohemian Middle Mountains (Šebek 1962, map; Kotlaba 1984, map). 1961 it was found near Mücheln in central Germany (Dörfelt 1974, map), 1977 near Bielinek nad Odra (Skirgiełło 1977), and more recently near Pyrzyce in north-western Poland and near Przemysl (Wojewoda 2003). 1990 it was found near Ribnitz in northeastern Germany (J. Duty unpubl.). There are no records from western Germany, Netherlands, Denmark, and Scandinavia.

Tulostoma giovanellae Bres. [T. volvulatum Borszcz. ss. Hollós]. The mediterranean species appeared around 1900 near Kecskemét and Budapest, Hungary (Hollós 1904), later in Wiener Neustadt, Austria (Lohwag 1933), and again in Budapest (Bohus, Babos 1977), 1971-1974 in Potsdam, eastern Germany (Kre is el 1984). 
All the central European occurrences had an ephemerous and synanthropic character, near house walls in towns.

Tulostoma pulchellum Sacc. [T. hollosii Z. Moravec]. The species of wide continental distribution (it is known from North America as T. poculatum V. S. White, and originally from Australia) was illustrated from Hungary by Hollós (1904, as T. fimbriatum) and is known from south-western Slovakia and central Bohemia (Pouzar in Pilát 1958). Surprisingly it was collected 1967 - 1970 near Berlin (Kreisel 2004).

Tulostoma squamosum J. F. Gmel.: Pers. The striking species has its main distribution in the Mediterranean region and Middle East, but has been collected in Germany as early as in 19 th century $(1868,1879)$ at several sites in Berlin where it now is extinct. More recent records are from other regions of Germany: $1956 \mathrm{ff}$. Kyffhäuser Mts. in central Germany (Ra u schert 1956), 1962 Waren in north-eastern Germany, before 1980 near Bruchsal in the upper Rhine valley and 1987 on the Frisian island Borkum (Kre is el 1984, map; Krieglsteiner 1991, maps; Wöld ecke 1998). A record from Poland was before 1991 near Toruń (Wojew o da 2003), while the occurrence in Scandinavia is doubtful.

\section{DISCUSSION}

Since about 15000 years, large areas in northern Germany and northern Poland, which had been covered by inland ice during the last (Weichsel) glaciation of pleistocene, have been reoccupied by vegetation and by mycoflora - insomuch every species of Fungi which we actually observe in these areas, has reacted to a long-term global warming. It was the German microbiologist August Rippel (in 1940, quoted in Rippel-Baldes 1955: 187) who assumed that the soil-inhabiting mould Aspergillus niger Tiegh. was spreading in Germany from south to north during postglacial period. Actually it is widely accepted that we are living in a period of accelerated warming, caused by human activities. It is to expect that this recent process is reflected also by changes in the mycoflora.

If an organism seems to extend its distribution in a certain direction, two causes may be assumed:

1. the limits of distribution are really extending; 2 . the knowledge of the organism is expanding from one region to the next one. Which of these facilities is real in a special case, can be decided only by comparison of similar cases in neighboured regions. In case that parallel evolutions, or continued expansions, have been noted in various regions and countries, it can be concluded that the taxon really has extended its area.

Indroduction of additional organisms into a given territory may be due to two processes: either by anthopochory (neomycetes, as listed by Kreisel, Scholler 1994), often followed by a continuous expansion with broad front-line, or by spontaneous expansion, often marked at first only by unstable outpost-like occurrence (astathomycetes, Kre is el 2004). Both kinds of processes may be combined, as described above in the cases of Clathrus archeri, Mutinus elegans, M. ravenelii, which have been introduced from other continents to Europe, but have expanded continuously their distribution on this continent in the frame of their climatic ecological amplitudes. 
Apart of anthropochory and climatic evolution, a third factor seems to have influence on expansion of fungal areas: the eutrophication, in particular with nitrogen, by excessive and careless enrichment of landscape with nutrients and fertilizers. Mycenastrum corium is an excellent example for the changing frequency and distribution of a nitrophilous species in eastern Germany in dependence of changing agricultural strategies.

Most of the fungal species, suggested in the statements above as examples for expansion from south to north as a consequence of global warming, are wood-destroying Basidio mycetes (saprobes and tree parasites; section A). A lesser number of ectomycorrhizal Basidiomycetes (section C), and at least one of the soil-inhabiting saprobes (Agaricus bohusii, section B) can be added. In these categories, it seems that the greater river valleys with their floodplain forests and dunes (Rhine, Inn, Elbe/Laba, Oder/Odra, and perhaps Vistula) have much favoured the expansion process from south to north - as can be noted in the cases of Auricularia mesenterica, Coriolopsis trogii, Pluteus aurantiorugosus, Agaricus bohusii, and Chalciporus rubinus.

Category D, soil-inhabiting fungi of steppes and semide-serts, is the most problematic in this context, for the main direction of their expansion seems to be more from east and south-east to west, and anthropochory and eutrophication apparently play an important role in expansion. Nevertheless, a "climatic continentalization" has been claimed as a factor for their unexpected and unstable appearence in central Europe (Dörfelt, Bresinsky 2003).

Strangely enough, no representant of Ascomycetes could be included in one of the four sections. It may be due to their mode of spore dispersal and their diaspore survival during long-distance transports, that Ascomycetes cannot respond to climatic changes in the same degree as Basidiomycetes.

Acknowledgements: The author thanks for helpful suggestions and communications to Dr. Dieter Benkert (Potsdam), Reinhard Conrad (Gera), Christine Morgner (Bergen/Vogtland), Siegmund Olm (Neuenkirchen), Dr. Markus Scholler (Karlsruhe), Dr. Wolfgang Tietze (Zittau), and Benno Westphal (Bobitz).

\section{REFERENCES}

Andersson H. 2004. Internet.

Anderss on O. 1941. Bidrag til Skånes Flora 10. Botaniska Notiser 1941: 393406.

Arnolds E., Kuyper Th. W., Noordeloos M. E. (eds) 1995. Overzicht van de Paddestoelen in Nederland. Nederlandse Mycologische Vereniging, Wijster. 872 pp.

Arwi ds s on T. 1945. Secotium agaricoides (Czern.) Holl. I Sverige. Svensk Bot. Tidsskrift 39: 137 140.

Benkert D. 1971. Inonotus nidus pici Pilát und Conocybe intrusa (Peck) Sing., zwei für die Mykoflora der DDR neue Arten. Feddes Repert. 81: 654658.

Benkert D. 1973. Floristische Neufunde aus Brandenburg und der Altmark. Gleditschia 1: 51 166.

Benkert D. 2004. Die Mark Brandenburg, auch ein Einwande rungsland für Pilze. Verh. Bot. Ver. Berlin Brandenburg 137: 489514.

Benkert D. 2005. Die Pilzflora des Späth Arboretums in Berlin Baumschulenweg. Verh. Bot. Ver. Ber lin Brandenburg 138: 4782.

Benkert D., Jentsch H. 1985. Mutinus ravenelii und M. elegans in Brandenburg. Gleditschia 13: 231 234.

Bicha V. 1986. Psivka Ravenelova Mutinus ravenelii (Berk. et Curt.) E. Fischer v jižních Čechách. Mykol. Sborník 63: 143144. 
Bjørneka e r K., B u chwald F. N. 1933. Om Kløvblad (Schizophyllum alneum (L.) Schröt.) i Danmark. Friesia 1: 95108.

Bohlin A. 1971. Ganoderma pfeifferi Bres., ny art för Sverige. Göteborgs svampklubb Årsskrift 1971: 1314.

Bohus G., B ab os M. 1977. Fungorum rariorum icones coloratae. VIII. Vaduz, J. Cramer, 19 pp.

Bohus J ense n E., Ryman S., Strid A. 1990. Floccularia straminea, flockskivlingen, i Sverige. Jord stjärnan 11: 5262 .

Borg e n T. 1977. Mycenastrum corium på Bornholm, Danmark. Friesia 11 (2): 135137.

Brandrud E. 2001. Dødssopper på Rykkinn! Blekksoppen 29 (85): 2023.

Bujakiewicz A., Lisiewska M. 1983. The mycoflora of plant communities in the Słowiński National Park. Bad. Fizjogr. Pol. Zach., Ser. B, 34: 4977.

Doll R. 2001. Mykologische Beiträge aus Nordostdeutschland. 4. Boletus 14 (1): 1928.

Dörfelt H. 1974. Beiträge zur Pilzgeographie des herzynischen Trockengebietes. 2. Thermophile Ele mente der Pilz flora. Hercynia N. F. 11: 495431.

Dörfelt H. 1989. Amanita vittadinii in der DDR. Mykol. Mitt. 32 (3): 7174.

Dörfelt H., Bresinsky A. 2003. Die Verbreitung und Ökologie ausgewählter Makromyceten Deutschlands. Z. Mykol. 69 (2): 177286.

Dörfelt H., Kreisel H., Benkert D. 1979. Karten zur Pflanzenverbreitung in der DDR. 2. Serie: Die Erdsterne (Geastrales) der Deutschen Demokratischen Republik. Hercynia N. F. 16 (1): 156.

Dörfelt H., Kreisel H., Benkert D. 1988. Karten zur Pflanzenverbreitung in der DDR. 7. Serie. Ausgewählte Makromyzeten (II). Hercynia N. F. 25 (1): 84106.

Dörfelt H., Richter U. 1996. Montagnea radiosa, der Wüstentintling ein Wiederfund und seine Bedeutung für den Pilzschutz. Boletus 20 (3): 9891.

Dunge r I. 1987. Kartierung der Porlinge (porige Polyporales und Poriales) in der Oberlausitz. I. Ver breitung und Ökologie der Arten. Abh. Ber. Naturkundemus. Görlitz 60 (11): 1160.

Eckblad F. E. 1992. Laerball Mycenastrum corium endelig funnet i Norge. Blekksoppen 20 (58): 3234.

Eder M. 1983. Massenvorkommen des Ansehnlichen Samthäubchens im Freiland. Mykol. Mitt. 26: 8283.

Guld en G. 2002. Ny norsk skjermsopp, Pluteus aurantioru gosus, funnet i Oslo. Blekksoppen 30 (88): 1113.

Gu mińs k a B. 1985. Mutinus ravenelii (Berk. et Curt.) E. Fischer (Phallales, Mycota) nowy gatunek dla flory Polski. Zesz. Nauk. UJ 752, Prace Botaniczne 13: 97103.

Hansen L. 1962. A Danish find of Mycenastrum corium with notes on its anatomy. Botanisk Titdsskrift 58: 204212.

Hansen L., Knudsen H. (ed.) 1992. Nordic Macromycetes. 2. Copenhagen, Nordsvamp, 474 pp.

Hansen L., Knudsen H. (ed.) 1997. Nordic Macromycetes. 3. Copenhagen, Nordsvamp, 444 pp.

Hardtke H. J., Otto P. 1998. Kommentierte Artenliste Pilze. Materialien zu Naturschutz und Land schaftspflege, Freistaat Sachsen. 217 pp.

Herk C. M., Aptro ot A., D obber H. F. 2002. Long term monitoring in the Netherlands suggests that lichens respond to global warming. Lichenologist 34: 115.

Herrmann M. 1962. Der Tintenfischpilz Anthurus archeri (Berk.) E. Fischer erstmals in der DDR beobachtet. Mykol. Mitt. 6 (1): 49.

Herrmann M. 1971. Armillaria luteovirens an drei Stellen in der DDR gefunden. Mykol. Mitt. 15: 6567.

Herrmann M. 1971. Neue Funde des Tintenfischpilzes in der DDR und den angrenzenden Ländern. Mykol. Mitt. 15: 7475.

Herrmann M. 1976. Drei weitere Conocybe intrusa Funde in Europa. Mykol. Mitt. 20 (1): 2122.

Herrmann M. 1987. Der Spindelfüßige Egerling Agaricus bohusii ein Massenpilz der Elsteraue. Mykol. Mitt. 30: 33 36.

Hollós L. 1904. Die Gasteromyceten Ungarns. Leipzig, Oswald Weigel, 278 pp.

Jahn H. 1963. Mitteleuropäische Porlinge (Polyporaceae s. lato) und ihr Vorkommen in Westfalen. Westfälische Pilzbriefe 4: 1143.

Järva L., Vimb a E. 1981. Maarasva muunad ehk seened tanu all. Eesti Loodus 24 (9): 197199.

Kaspar R. 1979. Funalia trogii in der DDR. Boletus 3 (1): 12. 
Kers L. E. 1980. Fynd av Gastrosporium simplex och Cordyceps canadensis i Sverige. Svensk Botan. Tidskrift 74: 2930.

Kle in e J., Kle mm D., Rohland P. 2004. Der Kurzsporige Röhrling (Chalciporus rubinus) in Leipzig (Sachsen). Boletus 27 (1): 3742.

Kluzák Z. 1990. Vierteljahrhundert von Tintenfischpilz Clathrus archeri in der Tschechoslowakei. Sborník Jihočesk. Muz. v České Budějovica, Přir. Vědy, 30: 5766.

Knudsen H., Pedersen A. 1980. Judasøre under spredning i Danmark. Svampe 1: 1926.

Knudsen H., Pedersen A. 1983. Kløvblads udbredelse i Danmark. Svampe 8: 6672.

Kotlab a F. 1984. Zeměpisné rozšíření a ekologie chorošů (Polyporales s. 1.) v Československu. Praha, Academia. 194 pp. + Karten

Kre ise1 H. 1962. Trametes extenuata und Trametes trogii in Deutschland. Ber. Bayer. Bot. Ges. 35: 55 56.

Kreisel H. 1982. Das Vorkommen von Mycenastrum corium in der DDR. Gleditschia 9: 257269.

Kre is el H. 1984. Die Stielboviste (Gattung Tulostoma) der Deutschen Demokratischen Republik und Westberlins. Hercynia, N. F., 21: 376416.

Kre is e 1 H. (ed.) 1987. Pilzflora der Deutschen Demokratischen Republik. Basidiomycetes. Jena, VEB Gustav Fischer Verlag. 281 pp.

Kr e is el H. 1991. Breitet sich Sarcodontia crocea nach Norden aus? Boletus 15 (1): 1920.

Kr e is el H. 1994. Der Spechtloch Schillerporling (Inonotus nidus pici Pilát). Pilz 1 (3): 12.

Kreis el H. (1995, ersch. 1996). Endoptychum agaricoides, der Säulenstäubling, bei Potsdam. Boletus 19 (3): 6568.

Kre ise 1 H. 1998. Zur Verbreitung einiger Porlinge in Ostdeutschland. Gleditschia 26 (1/2): 145153.

Kr e is el H. 2000. Beiträge zur Pilzflora von Vorpommern. Gleditschia 28 (1/2): 8191.

Kre isel H. 2004. Globalisierung der Pilzflora. Verhandl. Bot. Ver. Berlin Brandenburg 137: 4352.

Kre ise1 H. 2004. Beiträge zur Pilzflora von Mecklenburg Vorpommern (Deutschland). Feddes Repert. $115(1 / 2): 6277$.

Kreise1 H. 2004. Tulostoma pulchellum in Brandenburg neu für Deutschland. Z. Mykol. 70 (1): 107 110.

Kreisel H. 2005. Beiträge zur Pilzflora von Mecklenburg Vorpommern (Deutschland). Feddes Re pert. $116(3 / 4): 201217$.

Kreis el H., Scholle r M. 1994. Chronology of Phytopsrasitic Fungi Introduced to Germany and Ad jacent Countries. Botanica Acta 107 (6): 369472.

Krieglsteiner G. J. 2001. Verbreitungsatlas der Großpilze Deutschlands (West). Band 1, Teile A / B. Stuttgart, Verlag Eugen Ulmer. 1016 pp.

Kuthan J., Veselský J. 1967. Psivka Ravenelova Mutinus ravenelii (Berk. et Curt.) E. Fischer v Československu. Česká Mykol. 21 (2): $112166+$ tab. XII.

Lang e J. E. 1936. Flora Agaricina Danica. Vol. 2. Recato A/S. Copenhagen. 101 pp., pl. 4180.

La r s s on K. H. (ed.) 1997. Rödlistade svampar i Sverige. Artfakta. Uppsala, Artdatenbanken. 547 pp.

Lohmeyer T. R. 2003. Porlinge zwischen Inn und Salzach eine Zwischenbilanz nach dreißig Jahren. Teil VI. Mycologia Bavarica 6: 4150.

Lohwag H. 1933. Seltene Gasteromyceten aus dem Burgenlande. Schweiz. Z. Pilzkunde 11: 8084.

Lundqvist N. 1961. Nyare och äldre svenska fynd av Gasteromyceten Mycenastrum corium (Guers.) Desv. Svensk Bot. Tidskr. 55: 613615.

N a u t a M. M., Velling a E. C. 1995. Atlas van de Nederlandse paddestoelen. Rotterdam. 352 pp.

Niemelä T., Kotiranta H., Pentilä R. 1992. New records of rare and threatened polypores in Fin land. Karstenia 32 (2): 8194.

Olofss on D. 1996. Tickor i Sverige. Projektrapport 1996. 127 pp.

Ot to P., et al. 1994. Karten zur Pilzverbreitung in Ostdeutschland. 11. Serie: Ausgewählte Giftpilze. Gleditschia 22 (2): 339364.

Otto P. et al. 2005. Karten zur Pilzverbreitung in Ostdeutschland. 17. Serie: Ausgewählte Arten der Auenwälder und Weidengebüsche. Boletus 27 (2): 95123.

Peter se n J. H. 1983. Lakporesvampe (Ganoderma) i Danmark og Europa. Svampe 7: 111.

Petersen J. H. 2006: Krumskaellet Champignon (Agaricus bohusii) en ny art for Danmark. Svampe 53: 5758.

Pilát A. 1936. Polyporaceae Houby chorošovité. Atlas hub evropských. Praha. 624 pp.

Pilát A. ed. 1958. Gasteromycetes. In Flora ČSR, Ser. B. vol. 1. Čskolov. Akad. Věd. Praha. 
Pilát A., Der mek A. 1974. Hríbovité Huby. Bratislava, Veda. 206 pp.

Rahmstorf S., Schellnhuber H. J. 2006. Der Klimawandel. Beck'sche Reihe.

Rauschert R., Hellmund R. 1989. Zwei exotische Pilzarten (Mutinus elegans und Lepiota rhyparo phora) in der Stadt Halle. Mykol. Mitt. 32 (3): 7580.

Ra uschert S. 1956. Die Steppentrüffel Gastrosporium simplex Matt. in Mitteldeutschland. Z. Pilzkun de 22 (3): 8082.

Rauschert S. 1962. Polyporus rhizophilus Pat., ein für Deutschland neuer Steppenpilz. Westfäl. Pilz briefe 3 (4): 6872.

Rauschert S. 1964. Montagnea arenaria (DC. ex Fr.) Zeller, ein für Deutschland neuer Steppenpilz. Westfäl. Pilzbriefe 5 (1): 113.

Rich te r D. 2005, 2006. Klima und Pilze. Eine Untersuchung zum Einfluss des Klimas auf das Pilzwachs tum und dessen langzeitliche Veränderungen. Der Tintling 10 (4): 33 50,11 (1): 3847.

Richter U., Schurig B. 1997. Massenvorkommen der Blassen Borstentramete, Coriolopsis trogii, in Sachsen Anhalt. Boletus 21 (2): 117118.

Rippel Baldes A. 1955. Grundriss der Mikrobiologie. 3. Aufl. Berlin, Göttingen, Heidelberg, Sprin ger Verlag. $418 \mathrm{pp}$.

Ry ma n S., Holmås e n I. 1984. Svampar. En fälthandbok. Stockholm, Interpublishing. 718 pp.

Schumacher R. K. 2005. Der Gelbe Apfelbaum Stachelschwamm (Sarcodontia crocea) verbreitet und dennoch gefährdet. Boletus 28 (1): 1923.

Šebek S. 1962. Nový nález choroše trávního Polyporus rhizophilus (Pat.) Sacc. Česká Mykol. 16 (1): 1418.

Se dláček J.,Skála E. 1985. Psivka Ravenelova Mutinus ravenelii (Berk. et Curt.) E. Fischer v sever ních Čechách. Mykol. Sborník 62: 106109.

Skirgiełło A. 1977. Materiały do poznania rozmieszczenia geograficznego grzybów wyższych w Euro pie. 5. Acta Mycol. 12: 155189.

Skirgiełło A. 1986. Materiały do poznania rozmieszczenia geograficznego grzybów wyższych w Euro pie. 6. Acta Mycol. 20 (1): 129157.

Specht P. 2005. Schuppige Egerlinge. Zwei gut zu trennende Arten (A. bohusii, A. vaporarius). Der Tintling 10 (3): 4044.

Stengl Rejthar A., Wojewoda W. 1985. Expansion of the fungus Clathrus archeri (Berk.) Dring (Gasteromycetes) in Europe and Poland. Zesz. Nauk. Uniw. Jagiełf. 752, Prace Botan. 13: 105110.

Stomps T. J. 1931. Über das Auftreten von Mutinus elegans in Europa sowie von Clathrus treubii auf Sumatra. Ber. Deutsch. Bot. Ges. 49: 5260.

Stricker P. 1954. Die Ausbreitung des Tintenfischpilzes Anthurus aseroeformis McAlpine (Anthurus Muellerianus Kalchbr.). Beitr. Naturk. Forschung Südwestdeutschland 13: 9398.

Sunhede S. 1989. Geastraceae (Basidiomycotina). Morphology, ecology, and systematic with special emphasis on the North European countries. Fungiflora, Oslo. 535 pp.

Täglich U. (ed.) 1999. Checkliste der Pilze Sachsen Anhalts. Halle/S., Landesamt für Umweltschutz. $217 \mathrm{pp}$.

Te o d o r ow i z F. 1939. Nowe dla flory polskiej podrzędy, rodziny, rodzaje i gatunki wnętrzniaków (Ga steromycetes). Kosmos 64 (1): 83107.

Ulbrich E. 1937. Mutinus inopinatus Ulbrich n. sp., eine neue Phalloidee aus Deutschland. Ber. Deutsch. Bot. Ges. 55: 493504.

Un ge r H. G. 1994. Regionale Rote Liste Lübeck. Großpilze. Umweltamt, Hansestadt Lübeck. 48 pp.

U rb on as V., Kala me es K., Luk in V. 1986. Conspectus florum Agaricalium fungorum (Agaricales s. 1.) Lithuaniae, Latviae et Estoniae, Vilnius. 140 pp.

Vimba E., Yarva L. 1981. Mutinus ravenelii (Berk. et Curt.) E. Fisch. v Sovetskom Sojuze. Mikol. Fitopatol. 15 (59): 372374.

Wint ter h off W. 2000. Epigäische Gasteromycetanae. (In:) G. J. Kri i g 1 st e in e r (ed.). Die Großpilze Baden Württembergs 2. Stuttgart, Verlag Eugen Ulmer: 103193.

Woje wo da W. 1973. Sarcodontia setosa (Pers.) Donk w Polsce. Fragm. Flor. Geobot. 19: 469473.

Wojew od a W. 2003. Checklist of Polish larger Basidiomycetes. (In:) Z. Mirek (ed.). Biodiversity of Poland 7. W. Szafer Institute of Botany, Polish Academy of Sciences, Kraków. 812 pp.

Wöldecke K. 1998. Die Großpilze Niedersachsens und Bremens. Niedersächsisches Landesamt für Ökologie, Hannover. 538 pp. 
Globalne ocieplenie a mikoflora regionu Bałtyku

\section{Streszczenie}

Autor omawia możliwe skutki globalnego ocieplenia na rozmieszczenie i ekologię grzy bów makroskopowych oraz przedstawia przykłady sugerowanych gatunków wskaźnikowych, które są wyraźnie rozprzestrzenione od południa do północy. Opracowanie dotyczy jedynie Basidiomycetes, gdyż nie jest znany żaden przypadek niezlichenizowanych Ascomycetes. Au tor rekomenduje ciągły monitoring wymienionych gatunków. 
